University of Pennsylvania Carey Law School

Penn Law: Legal Scholarship Repository

Faculty Scholarship at Penn Law

$11-28-2017$

\title{
An Unsung Success Story: A Forty-Year Retrospective on U.S. Communications Policy
}

Christopher S. Yoo

University of Pennsylvania Carey Law School

Follow this and additional works at: https://scholarship.law.upenn.edu/faculty_scholarship

Part of the Antitrust and Trade Regulation Commons, Communications Law Commons, Communication Technology and New Media Commons, Digital Communications and Networking Commons, Internet Law Commons, Law and Economics Commons, Legal History Commons, Mass Communication Commons, and the Television Commons

\section{Repository Citation}

Yoo, Christopher S., "An Unsung Success Story: A Forty-Year Retrospective on U.S. Communications Policy" (2017). Faculty Scholarship at Penn Law. 1957.

https://scholarship.law.upenn.edu/faculty_scholarship/1957

This Article is brought to you for free and open access by Penn Law: Legal Scholarship Repository. It has been accepted for inclusion in Faculty Scholarship at Penn Law by an authorized administrator of Penn Law: Legal Scholarship Repository. For more information, please contact PennlawIR@law.upenn.edu. 


\title{
An Unsung Success Story: A Forty-Year Retrospective on U.S. Communications Policy
}

\begin{abstract}
Looking backwards on the occasion of Telecommunications Policy's fortieth anniversary reveals just how far U.S. communications policy has come. All of the major challenges of 1976, such as promoting competition in customer premises equipment, long distance, and television networking, have largely been overcome. Moreover, new issues that emerged later, such as competition in local telephone service and multichannel video program distribution, have also largely been solved. More often than not, the solution has been the result of structural changes that enhanced facilities-based competition rather than agency-imposed behavioral requirements. Moreover, close inspection reveals that in most cases, prodding by the courts often served as a key institutional catalyst for change.
\end{abstract}

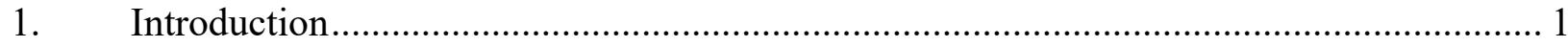

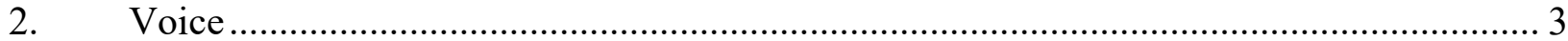

2.1. Customer Premises Equipment (CPE) ..................................................... 4

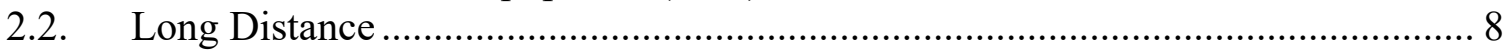

2.3. Local Service ..................................................................................... 9

2.3.1. The Failure of Access-Based Competition ........................................... 10

2.3.2. The Success of Facilities-Based Competition...................................... 16

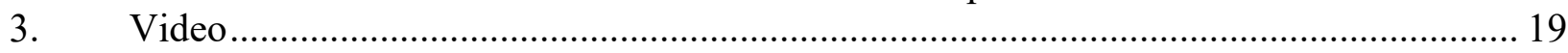

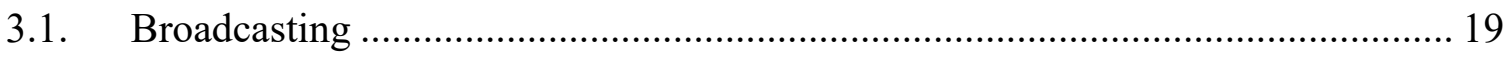

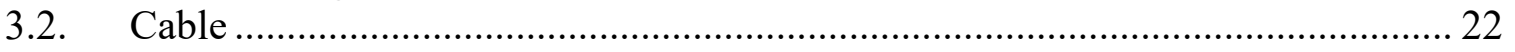

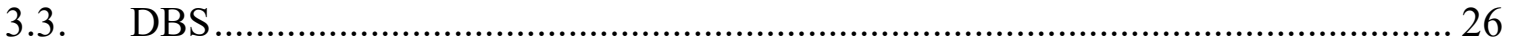

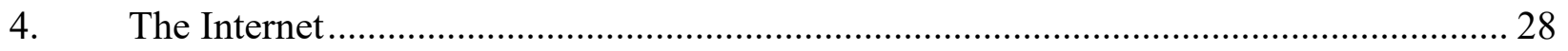

5. Conclusion and a Look to the Future ...................................................................... 32

\section{Introduction}

Since the very beginning, the goal of Telecommunications Policy has been to provide a venue for academics to offer policy guidance to key actors (Day, 1976a). It arose at a time when government officials, academics, and industry actors were just starting to create venues to explore the increasingly complex issues posed by developments such as the emergence of cable 
television and the impending breakup of AT\&T. ${ }^{1}$ The Journal has consistently offered a home for influential articles that have framed and shaped a wide range of critical regulatory decisions.

One inevitable consequence of such a mission is that the articles that have graced the Journal's pages have looked forward and concentrated on the next set of challenges that must be surmounted. The result has been a tendency to focus on the part of the glass that remains half empty and to downplay, if not ignore, the part of the glass that has become half full. This special issue commemorating Telecommunications Policy's fortieth anniversary provides a welcome opportunity to look backward instead of forward and to offer a long-term assessment of how far U.S. communications policy has come.

Recall the central challenges that dominated the telecommunications policy agenda in December 1976. For voice, U.S. policymakers were trying to promote competition in customer premises equipment $(\mathrm{CPE})^{2}$ and long distance both through regulation and the ongoing antitrust case that would eventually lead to the breakup of AT\&T. At this point, competition in local telephone service was still viewed as impossible.

With respect to video, one major concern was the decades-long dominance of three broadcast television networks and the potential for them to exercise vertical market power against the movie studios and local broadcast stations. Moreover, cable television had existed for nearly three decades, but had yet to achieve widespread consumer acceptance and remained

$1 \quad$ Another prominent example was the Airlie House Conference that would eventually evolve into the annual Telecommunications Policy Research Conference (TPRC). Like Telecommunications Policy, TPRC has the goal of bringing together academics, policymakers, and industry leaders to engage with one another over cutting-edge research. Initially supported by the White House Office of Technology Policy, the Federal Communications Commission, and the Markle Foundation, this conference was described by this Journal as "a unique focus for policy research" (Dordick, 1977) as well as "the most important annual gathering of individuals interested in the specifics and scope of telecommunications policy research in the USA and, to a much lesser extent, internationally" (Day, 1976b).

2 CPE includes both residential equipment, such as handsets, as well as business equipment, such as switches known as public branch exchanges (PBXs). 
in regulatory limbo because of the lack of a clear resolution of the scope of the Federal Communications Commission's (FCC's) jurisdiction over this new technology.

Waiting in the wings was the technology that would fundamentally change all of communications policy and would eventually become one of the most pervasive influences in modern life: the Internet. As of 1976, however, the Internet remained more dream than reality, and technologies that combined communications with computing power had just begun to attract regulatory attention.

Looking back from the vantage point of forty years down the road, what is perhaps most striking is the extent to which these challenges have largely been solved. In most cases, the solution has been the result of structural changes that enhanced facilities-based competition rather than agency-imposed behavioral requirements. Moreover, close inspection reveals that in most cases, prodding by the courts often served as a key institutional catalyst for change.

\section{Voice}

Regarding conventional telephone service, the policy problems confronting the U.S. in December 1976 were somewhat different from those confronting the rest of the world. Other countries were striving to increase low telephone penetration rates and to improve the poor performance of government-owned systems that would eventually lead to the privatization wave that swept the industry during the 1980s and 1990s. The U.S., in contrast, had already achieved a household penetration rate of over $90 \%$ by 1970 (U.S. Census, 1975, 783) and had long been 
home to the only major telecommunications system in the world that was completely privately owned. ${ }^{3}$

Instead, the focus in the U.S. was on the breakdown of the previous belief that all aspects of the telephone system constituted a natural monopoly and the accompanying realization that multiple providers could serve portions of the network efficiently. In particular, regulators and antitrust courts had begun to focus on promoting competition in CPE and long distance. The possibility of competition in local telephone service would not emerge until later and would find its most concrete manifestation in the Telecommunications Act of 1996.

What is most striking is the extent to which each of these policy challenges have largely been resolved over the past forty years. The mechanism of change has been more the result of facilities-based competition than government-mandated behavioral requirements. Furthermore, a review of the history reveals how well-timed judicial interventions have played a critical role in driving these changes.

\subsection{Customer Premises Equipment (CPE)}

Until the late 1960s, few questioned the conventional wisdom that the entire telephone represented an integrated natural monopoly, all aspects of which had to be coordinated and controlled by a single entity. Consistent with this belief, the Bell System maintained strict control over all devices attached to its network. All handsets had to be manufactured by and leased from AT\&T's equipment subsidiary, Western Electric.

The Bell System enforced these requirements by including so-called foreign attachment provisions in its tariffs that prohibited subscribers from connecting equipment made by any other

3 For an analysis of the exceptional year during World War I when the federal government took over the U.S. telephone system, see Janson and Yoo (2013). 
manufacturer to the network. These restrictive policies regarding CPE had already led the 1949 government antitrust suit that was settled in 1956 by an agreement that allowed it to keep Western Electric, but required that it refrain from entering the computer business. ${ }^{4}$

Since that time, remarkably little innovation had occurred in handsets, which was limited to the introduction of the Princess phone in 1959 and the Trimline phone in 1965. Interestingly, Bell Labs had developed answering machine technology in 1950, but suppressed it out of concern that it would reduce telephone calling.

Over time, key decisionmakers began to recognize that the telephone network was more properly regarded as a series of separate, vertically related markets consisting of CPE, local service, long distance service, and the content and other collateral services provided through the network. Many of these markets were potentially open to competition. Of these, CPE was the most obvious candidate for reform.

By 1976, the Bell System's control over CPE was already under significant pressure, triggered by a seemingly trivial device known as the Hush-a-Phone. The Hush-a-Phone was a plastic cup that could be attached to a handset to limit the extent to which one person's phone conversation would interfere with and be disrupted by other conversations taking place in the same room. After considering the case for seven years, the FCC accepted the argument that this device violated the foreign attachment provisions contained in the Bell System's tariffs, only to see that decision struck down on judicial review because the U.S. Court of Appeals for the D.C. Circuit decided that consumers should be left to judge for themselves how best to use the network so long as that use did not interfere with others. Indeed, the proffered alternative 
(cupping your hand around the mouthpiece) had the same deleterious effects as the Hush-aPhone itself. ${ }^{5}$

The next landmark dispute over CPE arose with respect to the Carterfone, a device that extended the reach of the wireline telephone network by using an acoustical coupling to connect a telephone handset to a two-way radio. The Bell System raised objections based on network harm that were similar to the ones it raised with respect to the Hush-a-Phone. Again the FCC summarily rejected their objections in part based on the D.C. Circuit's reasoning in Hush-aPhone and in part based on the fact that the acoustical nature of the interconnection made the Bell System's concerns about aberrant electrical impulses patently pretextual (U.S. FCC, 1968a).

The agency eventually enacted new rules in authorizing subscribers to attach CPE made by any manufacturer so long as it complied with certain technical registration requirements. In the process, the agency criticized as unjust and unreasonable the Bell System's attempts to hamper competitive $\mathrm{CPE}$ by including provisions in its tariffs requiring that all customers wishing to use equipment manufactured by other companies to also employ a device known as a Protective Connection Arrangement (PCA) to buffer the network against any potential interference (U.S. FCC, 1975b; 1976d). A later court relied on the openly pretextual nature of the justifications for this new practice as the basis for subjecting the Bell System to antitrust liability. ${ }^{6}$

Concerns remained, however, that the Bell System would use its continuing dominance over local telephone service to cross subsidize its CPE operations and to handicap CPE competitors by restricting their access. Consequently, the FCC promulgated rules requiring that Bell provide CPE through separate subsidiaries (U.S. FCC, 1980a).

$5 \quad$ FCC (1955), rev'd, 238 F.2d 266 (D.C. Cir. 1956).

$6 \quad$ Litton Sys. Inc. v. AT\&T, 700 F.2d 785 (2d Cir. 1983). 
At roughly the same time that the $\mathrm{FCC}$ was attempting to promote competition in $\mathrm{CPE}$ through regulation, the U.S. Department of Justice's Antitrust Division launched an antitrust action against AT\&T primarily intended to make it spin off Western Electric. Rather than surrender its prized equipment subsidiary, AT\&T counterproposed that it divest its local telephone subsidiaries instead. To ensure that the newly divested local telephone companies did not simply replicate the restrictive practices of the old Bell System, the court order mandating the breakup of AT\&T barred them from manufacturing CPE. ${ }^{7}$ A subsequent regulation prohibited them from marketing equipment manufactured by other companies (U.S. FCC, 1983b). Finally, the Telecommunications Act of 1996 continued to require the Bell operating companies to place their manufacturing operations in a separate subsidiary until three years after the FCC had certified that their local telephone markets had become open to competition (47 U.S.C. $\S \S 272$, 273).

As of today, the promotion competition in CPE is clearly a problem that has been solved. The liberalization of the CPE market unleashed an incredible wave of innovation, covering a huge variety of cordless telephones, answering machines, fax machines, point-of-sale terminals, modems, and other devices. Prices also dropped precipitously, with fixed-line handsets now being widely available for purchase for only a few dollars. The history of this process also reflects a pattern that will be repeated in later cases: regulators at first accede to the arguments put forth by incumbent operators to limit competition, but eventually back off at the prodding of judicial decisions overturning these initial decisions.

$7 \quad$ United States v. AT\&T, 552. F. Supp. 131 (D.D.C. 1982), aff'd mem. sub nom. Maryland v. United States, 460 U.S. 1001 (1983). 


\subsection{Long Distance}

Long distance was the other part of the telecommunications network where competition had begun to emerge as of 1976. A company called Microwave Communications, Inc. (later better known by the acronym, MCI) had begun using microwave links to offer a switched long distance service known as Execunet in 1975. The FCC accepted the Bell System's argument that Execunet exceeded the terms of the special access tariff on which MCI had based this service, only to see those decisions overturned by the courts on the grounds that the FCC's interpretation of the tariff unnecessarily restricted competition. ${ }^{8}$ Again, the courts served as the primary proponent of increased competition over the objections of the regulators.

Simple approval of MCI's tariffs was not sufficient to promote full competition in long distance. New entrants struggled to compete during their initial years when their networks covered only part of the country. They sought to offer complete national coverage by obtaining access to AT\&T's long distance network to cover those areas not served by their own facilities. Regulatory efforts to mandate such access failed to promote competition in long distance (Faulhaber, 2003).

Instead, the antitrust decree that broke up AT\&T was the intervention primarily responsible for the emergence of a competitive long distance industry. The decree required that the Bell operating companies reconfigure phone switches that were initially designed to accommodate a single long distance provider to permit equal access by any long distance company. Equally importantly, the FCC placed local and long distance service into separate companies and imposed line-of-business restrictions that prevented the local telephone 
companies from providing long distance in order to eliminate the economic incentives for the local telephone companies to favor one long distance company over another.

These changes precipitated a sharp increase in the market share of long distance upstarts $\mathrm{MCI}$ and Sprint as well as a precipitous drop in long distance prices. Although providing the newly divested Bell operating companies with the ability of offering long distance service was the original driving force behind the Telecommunications Act of 1996, but the drop in long distance pricing has rendered this supposed benefit almost inconsequential. Indeed, long distance has become so cheap that wireless providers now typically count total minutes without differentiating between local and long distance calling.

The vantage point of today reveals that one of the central problems confronting communications policy forty years ago has been resolved quite decisively. The process reflects the same pattern in which the regulatory agency initially accepts the incumbent's arguments in favor of limiting competition, only to relent and embrace competition after some prodding by the courts through judicial review of FCC decisions and the alignment of incentives effected by the breakup of AT\&T.

\subsection{Local Service}

Local service is the last area of the telecommunications network to become competitive. Throughout the breakup of AT\&T during the 1980s, it was widely thought that local service continued to be a natural monopoly. It was not until the Telecommunications Act of 1996 that the promotion of local telephone competition came to be regarded as a realistic goal, and even then such competition was supposed to emerge by allowing competitors to borrow those portions of the incumbents' networks that retained natural monopoly characteristics. In the end, however, the advent of facilities-based competition first from wireless telephony and later through voice 
over Internet Protocol (VoIP) ultimately proved more effective in ending the local service monopoly than any behavioral regulation.

\subsubsection{The Failure of Access-Based Competition}

The 1996 Act envisioned that competition in local telephone service might follow one of three paths. First, an entrant might simply obtain access to all of the elements needed to provide local telephone service from the incumbent and resell them. Second, an entrant might build its own network from scratch. Third, an entrant may provide some of the elements needed to offer local telephone service and obtain the rest from the incumbent. To make this third option possible, Congress required every incumbent local telephone company to provide any other requesting carrier with access to any of its network elements on an unbundled basis at wholesale costs (called "unbundled network element" or “UNE” access) (47 U.S.C. § 251(c)(3)).

The way the first and third options were implemented essentially caused them to collapse into a single option. Resale prices were calculated from the top down by taking discounts from full retail prices that included a wide range of subsidies designed to further other social policies. UNE prices were calculated from the bottom up based on the long-run replacement cost based on the most efficient current technology through a methodology known as Total Element Long Run Incremental Cost (TELRIC). That meant that competitors seeking to provide service based on the incumbent's network without having any facilities of their own could effectively duplicate resale at lower cost by relying on UNE access to purchase the entire network piecemeal, a practice that became known as the UNE-Platform or UNE-P.

Local loop unbundling was embraced by the OECD, and soon nearly every country in the world had adopted it. That said, the 1996 Act is widely regarded as a failure in the U.S. In particular, unbundling failed to accomplish its primary objective of promoting competition in 
local telephone service, with the percentage of competitively provided local switched lines peaking at 13\% in 2004 before stabilizing at around 8\% (U.S. FCC, 2008b, tbl. 4; 2014c, 16). Unbundling presents a tradeoff between two different conceptions of efficiency. On the one hand, resale of the incumbents' networks at what amounts to wholesale price promises to benefit consumers by unleashing vigorous price competition as new entrants vie for customers by squeezing their margins. The drawback is that unbundling can dampen incentives to invest in new capacity. For projects that proved successful, however, the investor would be forced to share those benefits with all of its competitors at the wholesale cost, because it is based on a hypothetical network employing the most efficient technology is likely to be below actual cost. For projects that proved unsuccessful, investor would be forced to bear all of the costs. These limits on upside potential dampen the incentives for the incumbent to invest. At the same time, it deters new entrants from investing in alternative capacity by providing them with a path to obtain the same potential advantages associated with such investments without undertaking any of the risk. Competitors can simply wait until after the incumbent validates which parts of the network are viable before having to decide whether to enter. An incumbent who wants to avoid being left with a fistful of unprofitable investments must incur the costs of making a more accurate assessment of the quality of each particular market before making any investments (Yoo, 2002).

In short, lower prices come at the cost of lower incentives to invest. Whether to adopt unbundling depends on a comparison between the static efficiency gains from allocating the existing monopoly facility and the dynamic efficiency gains from investments in new capacity.

This is why Justice Breyer recognized in AT\&T v. Iowa Utilities Board that "a sharing requirement may diminish the original owner's incentive to keep up or to improve the property 
by depriving the owner of the fruits of value-creating investment, research, or labor." He further observed that one cannot "guarantee that firms will undertake the investment necessary to produce complex technological innovations knowing that any competitive advantage deriving from those innovations will be dissipated by the sharing requirement." " He similarly noted in Verizon v. FCC that compelling incumbents to share the cost-reducing benefits of a successful innovation destroys the incumbent's incentives to innovate in the first place. ${ }^{10}$

A majority of the Supreme Court later embraced Justice Breyer's concerns about access requirements' impact on the incumbents' incentives to reinvest in their networks in its 2004 Trinko decision. The Court recognized, "The mere possession of monopoly power, and the concomitant charging of monopoly prices, is not only not unlawful; it is an important element of the free-market system. The opportunity to charge monopoly prices - at least for a short periodis what attracts 'business acumen' in the first place; it induces risk taking that produces innovation and economic growth," including through investments in infrastructure. Because of that, "[c]ompelling such firms to share the source of their advantage ... may lessen the incentive for the monopolist, the rival, or both to invest in those economically beneficial facilities." ${ }^{11}$

Thus, as a purely theoretical matter, if the wholesale market made possible by unbundling were completely efficient, competitors would have little incentive to invest in new facilities. That said, as the Supreme Court noted in Verizon v. FCC, TELRIC contains certain inefficiencies that may cause UNE prices to exceed marginal cost and thus provide some incentive for investment. For example, although TELRIC bases its model on the most efficient technology currently available, it takes the locations of the incumbents' existing wire centers as

Id. at 428-29 (Breyer, J., concurring in part and dissenting in part). Verizon Commc'ns Inc. v. FCC, 535 U.S. 467 (2002) (Breyer, J., concurring in part and dissenting in part). Verizon Commc'ns Inc. v. Law Offices of Curtis V. Trinko, LLP, 540 U.S. 398, 408 (2004). 
given when calculating network costs. A new entrant with a more efficient physical configuration may find it cheaper to build its own facility. In addition, TELRIC rates are only adjusted every three to four years, which means that UNE access rates may be higher than the cost of building a new facility if costs have dropped since the last adjustment. Delays in becoming aware of when a new technology is "currently available" and in deploying that technology mean that UNE rates offer further reasons why UNE access rates may be higher than the cost of self-provisioning. To the extent that UNE prices are higher than the cost of selfprovisioning, new entrants may find investing in new facilities to be a better option. ${ }^{12}$

UNE access also poses difficult problems of administrability. As Justice Breyer noted in Iowa Utilities Board, “[e]ven the simplest kind of compelled sharing . . . can give rise to significant administrative and social costs." He continued: "The more complex the facilities, the more central their relation to the firm's managerial responsibilities, the more extensive the sharing demanded, the more likely these costs will become serious. And the more serious they become, the more likely they will offset any economic or competitive gain that a sharing requirement might otherwise provide." ${ }^{\prime 3}$

These conclusions were later endorsed by the entire Supreme Court in Trinko. Specifically, the Court recognized that UNE access affects components "deep within the bowels" of a local telephone network that can be made available only if "[n]ew systems [are] designed and implemented simply to make that access possible." Additionally, requests for unbundled access "are highly technical" and complications "are likely to be extremely numerous, given the

\footnotetext{
12535 U.S. at $504-07$.

13525 U.S. at 428-29 (Breyer, J., concurring in part and dissenting in part).
} 
incessant, complex, and constantly changing interaction of competitive and incumbent LECs implementing the sharing and interconnection obligations." 14

These additional considerations complicate the analysis of unbundling's likely success and render it impossible to resolve the merits of the policy as a matter of pure theory. Such questions are best resolved on the basis of the empirical evidence. Tellingly, a recent article appearing in this Journal surveying the empirical literature on the impact of unbundling concluded that "most of the evidence shows that local loop unbundling based on forward-looking cost methodology discourages both [incumbents] and [new entrants] from investing in networks" (Cambini and Jiang, 2009; 569). While it is theoretically plausible that UNE access could enable new entrants to climb the "ladder of investment" by providing stepping stones to full facilitiesbased competition as suggested by another article from this Journal (Cave, 2006), empirical analyses indicate that this has historically not been the case (see, e.g., Hausman and Sidak, 2005; Hazlett, 2006; Bourreau et al., 2010; Grajek and Röller, 2011).

These insights reinforce the reality that no policy, including unbundling, is universally beneficial. Instead, the better approach is to identify the circumstances under which a policy is likely to be beneficial. In the case of access regimes that require sharing of facilities, they make the most sense when entry is infeasible, since supracompetitive returns are unlikely to dissipate and any dampening of investment incentives are beside the point. Unbundling thus make sense for access to facilities that already exist and for which competitive entry is likely to be uneconomic.

The situation is quite different when entry and investment in new capacity are feasible and the way to attract new customers is investing in improved facilities rather than cutting price. 
When that is the case, the empirical evidence suggest that mandating unbundling and ratcheting down prices will only serve to eliminate the incentives to undertake the investments needed to dissipate the monopoly and to provide higher quality services.

This analysis underscores the importance of the U.S. Congress's decision to include two provisions in the unbundling provisions of the 1996 Act, which was designed to release the telephone system from UNE access requirements when entry becomes feasible. The statute requires when determining which network elements would be subject to the unbundled access requirement, the FCC consider at a minimum whether "access to such network elements as are proprietary in nature is necessary" and whether "the failure to provide access to such network elements would impair the ability of the telecommunications carrier seeking access to provide the services that it seeks to offer" (47 U.S.C. $§ 251(\mathrm{~d})(2)(A)-(B))$.

The U.S. courts rebuffed the FCC's first three attempts to implement these provisions because the agency had proffered interpretations that were permissive to the point where the statutory provisions did not provide any meaningful limits. In particular, the courts required that any interpretation of the necessary and impair provisions take into account whether the network elements to which access was sought were available through self-provisioning or from third parties, whether those elements exhibited the characteristics associated with natural monopoly (such as declining average costs or sunk costs), and whether the agency analyzed the impact on a market-by-market basis instead of simply drawing general conclusion. It was only after a fourth try, in an order in which the FCC eliminated unbundling requirements for voice switching, did the courts uphold the agency's interpretation of the necessary and impair requirements as valid.

The deregulation of voice switching effectively ended the U.S. experiment with unbundling for voice service a decade after it began. Tellingly, regulators repeatedly attempted 
to implement unbundling in a way that ignored the tradeoffs identified above. It was left to the courts to insist on interpretations of the statute that preserved investment incentives by lifting the unbundling requirement for elements that no longer exhibited natural monopoly characteristics and for which competition was feasible.

\subsubsection{The Success of Facilities-Based Competition}

Where access-based competition failed to promote entry in local telephone service, facilities-based competition succeeded, first in the form of cellular telephony and later augmented by voice over Internet Protocol (VoIP). In the U.S., mobile telephony surpassed traditional telephony in 2004 and has continued to grow, as fixed-line subscribership has entered a precipitous decline. Yet some suggest that the U.S. could have benefitted from cellular technology even sooner. Motorola Vice President Marty Cooper placed the first cellular telephone call in 1973. But U.S. providers did not begin to offer commercial cellular service until 1983, two years after Nordic Mobile Telephone launched commercial service in Scandinavian countries with U.S.-developed technology. Why did cellular service take so long to emerge in the U.S.? (Hazlett, 2017).

The answer lies in the somewhat desultory way that the FCC conducted its proceedings with respect to cellular. For example, two years after scientists at Bell Labs first conceived of cellular telephony in 1947, the FCC rejected AT\&T's request for an experimental license to begin developing cellular technology, stating that it was giving lower priority to services that were "more in the nature of a convenience or luxury" (U.S. FCC, 1949; see also U.S. FCC, 1951). When AT\&T formally requested that the FCC allocate spectrum to cellular communications in 1958, the agency took a decade to act on the request (U.S. FCC, 1968b). 
It was not until 1970 that the FCC agreed to reallocate spectrum previously set aside for UHF television to cellular (U.S. FCC, 1970a). Four years later, the FCC made clear its belief that the technical complexity and the need to spread the cost of providing service over a large user base meant that it expected cellular to be a natural monopoly (U.S. FCC, 1974a). The fact that the agency regarded cellular to be complement to, rather than a substitute for, conventional telephone service made assigning the monopoly license to the Bell System less problematic.

The agency soon began backing off this position, changing the rules in 1975 to allow any qualified carrier to apply for a license (U.S. FCC, 1975a). It was not until 1981 that the FCC formally adopted the order authorizing the issuance of cellular licenses. Regarding market structure, the FCC compromised by authorizing two cellular licenses in every market: one reserved for a new entrant and the other reserved for AT\&T (U.S. FCC, 1981). This indecisiveness delayed the emergence of cellular telephony by more than a decade. Economists estimate that this delay cost consumers tens of billions of dollars in foregone welfare (Rohlfs, Jackson, and Kelly, 1991; Hausman, 1997).

Although the causes of such regulatory delays are inevitably myriad, one principal reason is the regulators' vision of wireless as a complementary extension to the fixed-line network rather than a substitute for it. This belief manifested itself during the early years in the agency's initial presumption that the monopoly cellular license would be assigned to AT\&T. This lingering belief that cellular did not represent a substitute for conventional telephone service resulted in the inclusion of language in the 1996 Act's text and legislative history rejecting the idea that cellular service could constitute a facilities-based competitor (47 U.S.C. § 271(c)(1)(A); U.S. Congress, 1996). 
All of this began to change with the growth of a second generation of wireless technology in the form of broadband personal communications services (PCS), which the FCC authorized in 1995. The assignment of PCS licenses opened the cellular duopoly to greater competition. In 1998, the FCC recognized that PCS represented a new technology and was not subject to Congress's prohibition of treating cellular as a facilities-based competitor (U.S. FCC, 1998a; 2003a,b). Similarly, the FCC's Sixth Report on Wireless Competition recognized that "[f]or some, wireless service is no longer a complement to wireline service but has become the preferred method of communication" (U.S. FCC, 2001b, 13381).

In other contexts, however, the FCC continued to issue orders indicating that wireless telephony did not represent a substitute for traditional, fixed-line telephony during the 2000 s (U.S. FCC, 2004). In addition, state regulators have permitted competition from cellular to justify lifting regulatory restrictions on fixed-line local telephone service only grudgingly (see, e.g., Pennsylvania, 2015).

Since that time, wireless telephony has continued to soar, as fixed-line telephony has continued to dwindle. Indeed, the fact that almost no young people subscribe to fixed-line telephony raises serious questions about its future. The introduction of mass market VoIP services in 2004 has intensified the level of competition still further.

In the end, the final policy challenge in voice - the lack of competition in local telephone service — was solved by the emergence of vibrant facilities-based competition rather than through the managed-competition approach of local loop unbundling. Although wireless telephony ultimately emerged successful as an effective local service competitor, the slow speed with which regulators allocated spectrum arguably delayed its emergence as a competitive alternative 
by at least a decade. Unlike in the case of CPE, long distance, and unbundling, there were no major court decisions to prod the agency along.

\section{Video}

In addition to voice, the other major focus of U.S. communications policy during the late 1970s was video. The central policy problem in the video industry was the enduring dominance of the three largest broadcast networks: NBC, CBS, and ABC. The technology that would ultimately alleviate this problem—cable television—remained hamstrung by regulation until a series of judicial decisions unlocked the industry's potential as a pay television platform. The growing importance of cable in turn gave rise to a new concern: cable's emergence as the monopoly platform for multichannel video program distribution (MVPD). This new challenge would be overcome by the emergence of a new facilities-based competitor, direct broadcast satellites (DBS).

As was the case with voice, regulators sometimes made matters worse for video by ignoring the tradeoff between static and dynamic efficiency by relying on access regulation instead of facilities-based competition when entry was possible. In addition, court decisions overturning regulatory decisions often played a pivotal role in achieving the key policy goals.

\subsection{Broadcasting}

Since the earliest days of the broadcast television industry, policymakers had raised concerns about the longstanding triopoly of broadcast television networks comprised of NBC, CBS, and ABC. Ironically, the FCC's Network Inquiry would soon point out that the triopoly was the direct result of the Table of Allocations that the FCC used to deploy television stations in 1952. As of $1979,92 \%$ of the country was served by three operational broadcast television 
signals, while only $64 \%$ of the country was served by four signals, which meant that any fourth network would operate at a severe coverage handicap. Moreover, many of these fourth stations were UHF stations, which provided lower quality signals at higher operating costs. Taking the UHF handicap into account drops the percentage of the country with a fourth station with signal quality comparable to those of the incumbents to $34 \%$ (FCC, 1980c, 5, 68, 81).

Instead of trying to dissipate the triopoly by adding more television stations, the FCC focused its efforts on access regulation designed to limit the networks' ability to exercise oligopoly power against its channel partners. Early efforts, such as the Chain Broadcasting Rules and the 1958 Barrow Report, concentrated on protecting the exercise of market power downstream against the networks' local broadcast affiliates. ${ }^{15}$ By the 1970s, the focus had shifted more towards the exercise of market power upstream against the movie studios and other unaffiliated programmers.

The FCC's efforts to limit the exercise of market power of the television network triopoly against the movie studios were concentrated in two interventions undertaken in 1970. The Prime Time Access Rule (PTAR) required the networks to set aside one hour of programming between 7:00 pm and 11:00 pm for independent programming, although the rule made exceptions for merit programming such as public affairs, children's and documentary programming and made case-by-case exceptions for events such as the Rose Bowl and the Olympics. The Financial Interest and Syndication Rules (finsyn) limited the networks' ability to take ownership stakes in the programming that they televised, particularly with respect to syndicated reruns (U.S. FCC,

\footnotetext{
$15 \quad$ For an extended analysis of these efforts, see Yoo (2002).
} 
1970b). Both rules were paralleled by similar requirements enshrined in the 1977 consent decrees that settled the antitrust cases brought against all three networks in $1974 .{ }^{16}$

The FCC's efforts to curb the market power of the television networks were subject to the same tradeoff reflected in the unbundling discussion above. Limiting the profitability of networks could yield consumer benefits by lowering prices. At the same time, lowering the profitability of networking made entry by new networks more difficult. Such a discouragement is inconsequential when entry is impossible. But when entry is feasible, limiting the profitability of networking has the unfortunate side effect of foreclosing entry, thereby helping to cement the existing oligopoly into place.

The potential deterrent effect of PTAR and finsyn provided one reason that the FCC Network Inquiry recommended abandoning both rules in 1980 (U.S. FCC, 1980c, ch. VI). The FCC seriously considered abolishing PTAR in 1981 and even adopted a tentative decision in 1983 that would have repealed finsyn, but backed off in the face of congressional and industry pressure (U.S. FCC, 1983a).

The rules' potential problems were on full display when it came to the emergence of Fox as the fourth television network. The fledgling Fox network found that PTAR and finsyn to be significant impediments to its economic viability. Fox thus requested that the FCC initiate new proceedings to reevaluate both PTAR and finsyn and obtained waivers from both rules (U.S. FCC, 1990a, b). A sharply divided FCC responded by issuing new rules loosening finsyn, despite arguments by the U.S. Justice Department's Antitrust Division and the FCC's Chairman that the rules should be abolished in their entirety (U.S. FCC, 1991).

$16 \quad$ United States v. NBC, 449 F. Supp. 1127 (C.D. Cal. 1978), aff'd, 603 F.2d 227 (9th Cir. 1979); United States v. CBS, 1980-1 Trade Cas. (CCH) 9 63,594 (C.D. Cal. July 3, 1980), modified, 1988-2 Trade Cas. (CCH) ๆ 68,284 (C.D. Cal. Nov. 19, 1986); United States v. ABC, 1981-1 Trade Cas. (CCH) ๆ 64,150 (C.D. Cal. Nov. 14 , 1980). 
The court reviewing the 1991 revisions struck down the new rules as arbitrary and capricious. Facilities-based competition had undermined whatever market power the broadcast networks used to possess. Moreover, the court pointed out that finsyn had the unfortunate consequence of harming the independent program producers it was designed to protect. The networks were prevented from obtaining the syndication rights, which caused the networks to pay less for programming. It also forced the movie studios to assume the risk of whether a show would be a big enough hit to yield substantial syndication rights even when the larger size and broader portfolios of the broadcast networks placed them in a better position to bear those risks. The burdens of this inefficient risk bearing would weigh the heaviest on smaller program providers and producers of more experimental programming sources..$^{17}$

The FCC finally abolished both PTAR and finsyn in separate proceedings in 1995 (U.S. FCC, 1995a, b). The overall sweep of the history of these rules illustrates each of the major themes of this forty-year retrospective: that the problems that confronted video policy in the mid-1970s have now largely been solved, that decisions about how to address market power raise difficult tradeoffs between static and dynamic efficiency that favor the latter when entry is feasible, and that facilities-based competition and judicial review proved more effective in achieving the policy goals than did intensive regulatory oversight.

\subsection{Cable}

Although regulation did little to protect the movie studios from vertical market power or to promote the entry of new broadcast networks, the real catalyst for the emergence of more television networks was the advent of cable television. Freed of the channel limitations imposed

17 Schurz Commc'ns, Inc. v. FCC, 982 F.2d 1043 (7th Cir. 1992). 
by the localism-driven allocation of broadcast television stations, the growth of cable allowed the number of television networks to soar, reaching 565 by 2006 , which was the last year that the FCC reported the total number of cable networks (U.S. FCC, 2009).

It is somewhat ironic that an agency that was focused on promoting greater competition among television networks spent so much effort during the late 1960s and early 1970 s trying to curb cable's growth. Taking a position reminiscent to the one taken with respect to cellular telephony, the FCC regarded cable as a complement to broadcast television and thus created a series of rules designed to protect local broadcast stations in general and the fledgling UHF stations in particular. Beginning in 1965, the FCC began openly protecting the incumbent broadcasters by prohibiting cable operators from retransmitting signals from other cities that duplicated local programming (known as "network nonduplication") and required that cable operators carry all local broadcast stations (known as "must carry") (U.S. FCC, 1965). The FCC followed this with an order (later upheld by the U.S. Supreme Court) freezing further growth of cable in the top 100 markets until it could study the industry further (U.S. FCC, 1966). In 1969, the FCC also enacted "anti-siphoning" rules that strictly limited cable's ability to offer pay television service and requiring operators to originate local programming if they wanted to import distant signals (U.S. FCC, 1969).

The FCC lifted the cable freeze in 1972 and issued an order that enacted a cable "consensus" negotiated by the White House. It subjected cable operators in the top 100 markets to a must-carry requirement along with a fairly byzantine set of somewhat looser distant signal importation rules that turned on concepts such as market size, antileapfrogging, and syndicated exclusivity (syndex). It also imposed rules on local origination, franchising, and technical standards; authorized local oversight of cable rates; and required cable operators in the top 100 
markets to provide channels for public, educational, and governmental (PEG) access (U.S. FCC, 1972). The FCC gradually took steps to loosen the restrictions on distant signal importation still further. In 1974, the agency authorized distant signal importation during those hours when broadcast channels were dark (U.S. FCC, 1974b). It revised its rules again in 1976 to permit importation of foreign language and religious stations and network news feeds and to repeal the antileapfrogging rules, although it did extend the requirements requiring PEG access to all cable systems with 3,500 or more subscribers (U.S. FCC, 1976a,b,c,e). The agency also exempted small cable operators from its exclusivity and signal-carriage rules (U.S. FCC, 1977). The net result was to hamstring this fledging industry. As of 1976, cable had garnered only 10.8 million subscribers, and growth was steady, but slow (Besen and Crandall, 1981, 80).

The emergence of satellite as the preferred means for distributing cable content was about to transform the economics of the industry, beginning when Home Box Office (HBO) became the first cable network to distribute its feed via satellite nationally in September 1975. This was soon followed by satellite distribution of Ted Turner's Atlanta-based WTCG (later renamed WTBS and then TBS) in December 1976.

Even more important was a series of judicial decisions that struck down key elements of the FCC's restrictions on cable. In 1977, the U.S. Court of Appeals for the D.C. Circuit's decision in $H B O$ v. FCC criticized the FCC's conclusion that cable was a complement to broadcasting and invalidated the FCC's restrictions on pay cable as arbitrary and capricious as well as a violation of the First Amendment. ${ }^{18}$ In 1979, the Supreme Court's decision in FCC v. 
Midwest Video Corp. struck down the FCC's rules mandating that cable operators set aside channel capacity for PEG access and for leased access by unaffiliated programmers. ${ }^{19}$

The FCC's restrictions on cable were also influenced by FCC's Network Inquiry, a 1979 report by the FCC's Cable Bureau, and a series of significant studies published by the RAND Corporation. These influences led the FCC to respond by eliminating the distant signal importation and syndex rules in 1980, while retaining the rules governing network nonduplication and sports blackouts (U.S. FCC, 1980b). The 1984 Cable Act clearly established federal jurisdiction over cable and further deregulated the industry by preempting local rate regulation wherever the cable operator faced effective competition. It did impose a leased access requirement to benefit vertically unaffiliated programmers and authorized municipal licensing authorities to require franchisees to provide channels for public, educational, and governmental access (U.S. Congress, 1984, $\S \S 3,7,9$ ). Many of these access requirements have been criticized as being overly difficult to administer and having little to no real-world effect (see, e.g., Lampert, 1992). During the mid-1980s, the D.C. Circuit issued two additional decisions invaliding the must-carry rules on First Amendment grounds. Freed from these regulatory restrictions, the cable industry took off, reaching over 42 million subscribers by 1986 and peaking at 67 million in 2001 (U.S. FCC, 2005a, 14; 2017b, 570, 575).

Cable's maturation from an upstart underdog into a critical provider of video services raised concerns that the industry might be becoming too powerful. As a result, Congress began taking a more active role in placing restrictions on cable. It began by authorizing the FCC to reinstate syndex as part of the Satellite Home Viewer Act of 1988 (SHVA) (U.S. Congress, $1988, \S 203$ ), with the rules going into effect in 1990. The 1992 Cable Act restored must carry in 
a way that withstood First Amendment scrutiny, reauthorized local regulation of rates, and imposed access requirements on vertically integrated programmers and operators. At the same time the Act did prohibit exclusive cable franchising (U.S. Congress, 1992, $\S \S 3,4,5,7,11,19$ ).

The Telecommunications Act of 1996 returned cable to a more deregulatory trajectory, particularly through its provision requiring the deregulation of cable rates (U.S. Congress, 1996, $\S 301$ ). The FCC took another step by repealing the sports blackout rules in 2014 (U.S. FCC, 2014b). FCC Chairman Tom Wheeler also circulated a proposal in August 2015 to repeal the network non-duplication and syndicated exclusivity rules, only to back off two months later.

The cable history has thus proceeded in two distinct phases. Until the mid-1980s, cable followed a pattern similar to that followed by voice and to a lesser extent broadcast television, with interventions at key moments by court decisions overturning regulatory actions that favored incumbents helping the new technology to flourish. Beginning in the late 1980s, Congress became the key actor, first pursuing a re-regulatory and then a deregulatory course.

\subsection{DBS}

The primary justification for deregulating the cable industry is the growing competition from DBS. ${ }^{20}$ First pursued by Comsat in 1979, DBS accounted for 33.2\% of all MVPD subscribers by the end of 2015 (U.S. FCC 2017). An empirical analysis in the FCC's Report on Cable Industry Prices demonstrated that DBS has become a substitute for cable service (U.S. FCC, 2001a, 4363).

\footnotetext{
20 Other technologies, such as multichannel multipoint distribution systems (MMDS), satellite master antenna television (SMATV), and television receive only (TVRO) satellite dishes had potential, but failed to achieve widespread consumer acceptance.
} 
Closer examination of DBS history reveals that it has dealt with its share of bumps along the way. The interim rules the FCC adopted in 1982 imposed few restrictions on the fledgling industry, and the courts largely upheld that decision on judicial review (U.S. FCC, 1982). The capital requirements for launching a satellite capable of supporting DBS were significant. The industry squandered its first half decade on failed partnerships with companies such as Sears, Prudential, HBO, CBS, and TCI and fighting opposition from the broadcast industry. By 1985, most of the companies awarded licenses were bankrupt, and the industry was in disarray. DBS service would have to wait until DirecTV's successful launch in 1994. These facts reveal why the FCC declared DBS to be "one of the most successful new consumer electronics product introductions in history" in 1997 (U.S. FCC, 1997, 4377).

In the meantime, Congress had begun to impose some restrictions on DBS. The SHVA prohibited DBS from carrying local broadcast signals unless the area was unserved by broadcasting (U.S. Congress, 1988, § 202). The Satellite Home Viewer Improvement Act of 1999 (SHVIA) later revised this requirement to permit DBS providers to offer local broadcast stations so long as they carried all full-power broadcast signals available in their service areas (a requirement known as "carry one, carry all"). The SHVIA also extended the network nonduplication, syndicated exclusivity, and sports blackout rules to DBS. Although, as noted above, the sports blackout rules have since been repealed (U.S. Congress, 1999, $\S \S 1005,1008$ ).

The emergence of DBS as a competitor has eliminated the last major policy issues confronting video when Telecommunications Policy published its first issue. The vantage point of forty years later reveals that the solutions lay more in the advent of facilities-based competition and the timely intervention by the courts rather from agency-imposed access regulation, although in the case of DBS, the courts did not play a major role. 


\section{The Internet}

In December 1976, when Telecommunications Policy was first published, the Internet remained more of a dream than a reality. The article that set forth the TCP/IP protocol had been published only two years earlier (Cerf and Kahn, 1974), and the protocol would not be adopted as the basis of the Internet until 1983. The 1993 release of the first graphical web browser (Mosaic) and the 1995 release of the first complete HTML specification that turned the Internet into a mass-market phenomenon were not yet even on the horizon.

Even so, the FCC had begun to wrestle with how to regulate the services that combine transmission with computer processing that were the precursors to the modern Internet. The agency completed proceeding known as the First Computer Inquiry in 1971 (U.S. FCC, 1971). In 1980, the FCC concluded its Second Computer Inquiry, which would give rise to the distinction between basic and enhanced services. This distinction would serve as the foundation for the distinction between telecommunications and information services that is currently driving the network neutrality debate (U.S. FCC, 1980a).

But the real work of Internet regulation would not begin until the industry transitioned from dial-up connectivity, which was treated for the most part like any other telephone call, to broadband connectivity. Cable modem service was first tested in 1993 and deployed commercially in 1995, taking the early lead. Digital subscriber line (DSL) service was first offered to consumers in 1996, but did not enter widescale deployment until 1998. In the initial years, DSL was offered through tariffs (see, e.g. U.S. FCC, 1998b)

During this era, cable modem service was largely unregulated, and the FCC assiduously attempted to avoid resolving cable modem's proper regulatory classification, which prompted two Supreme Court Justices to suggest that the agency's failure to do so was arbitrary and 
capricious. $^{21}$ In 1999, the FCC's Line Sharing Order ruled that competitors who wished to provide DSL service did not need to lease the entire loop and could obtain UNE access to only the high-frequency portion of the loop needed to provide DSL service (U.S. FCC, 1999). The D.C. Circuit overturned this decision in 2002 because the FCC had failed to take into account cable modem's emergence as a vibrant competitor to DSL. ${ }^{22}$ In response, the FCC freed DSL from all major unbundling requirements when adopting its 2003 Triennial Review Order, a decision that was subsequently upheld by the courts. ${ }^{23}$

Finally, the FCC declared in 2002 that broadband via cable modem was an information service, a regulatory category essentially coextensive with the enhanced service category created by the Second Computer Inquiry, and not a telecommunications service (U.S. FCC, 2002). This was a momentous decision. Unlike other countries, which typically subject broadband to the regulatory regime developed to govern traditional telephone services, the FCC chose to create a sui generis regime under Title I of the Communications Act of 1934. The Supreme Court upheld the FCC's decision in Brand $X,{ }^{24}$ and shortly thereafter the FCC extended the same classification to DSL and other forms of broadband provided by telephone companies, broadband over powerline, and mobile broadband services (U.S. FCC, 2005b; 2006; 2007).

It is at this point that the debate over regulatory classification of broadband became inextricably bound up in the debate over network neutrality, a term that is usually attributed to $\mathrm{Wu}(2003)$ and explored in a dialogue between him and me at the same conference the following year (Yoo 2004; Wu 2004). At the same time that the FCC released its order declaring DSL to

\footnotetext{
$21 \quad$ National Cable \& Telecomm. Ass'n v. Gulf Power Co., 534 U.S. 327, 348-51 (2002) (Thomas, J., joined by Souter, J., concurring in part and dissenting in part).

$22 \quad$ U.S. Telecom Ass'n v. FCC, 290 F.3d at 428-30.

23 U.S. FCC (2003c).

$24 \quad$ National Cable \& Telecomm. Ass'n v. Brand X Internet Servs., 545 U.S. 967 (2005).
} 
be an information service, it issued a Policy Statement endorsing consumers' rights to access lawful content, run applications and use services. Consumers were also given the right to connect legal devices as they saw fit, but were subject to reasonable network management. The Policy Statement averred that it did not purport to adopt rules, but instead simply laid out principles that the agency planned to incorporate into its ongoing policymaking opportunities (U.S. FCC, $2005 \mathrm{c}) .^{25}$

Despite the fact that the Policy Statement explicitly stated that it was not creating enforceable rules, the FCC nonetheless attempted to sanction Comcast for violating the terms of the Policy Statement by sending TCP resets to slow down the BitTorrent file sharing system (U.S. FCC, 2008a). The D.C. Circuit overturned the FCC's decision in 2010, holding that Title I is not an independent grant of jurisdiction and can only be invoked in conjunction with a statutory provision that is an affirmative grant of authority to the agency. ${ }^{26}$

The FCC responded by adopting its 2010 Open Internet Order, which included rules mandating transparency and prohibiting blocking and unreasonable discrimination. The 2010 Order also applied a lower standard to mobile broadband and created exceptions for reasonable network management and specialized services (U.S. FCC, 2010). On judicial review, the D.C. Circuit ruled in 2014 that the affirmative grant of authority was sufficient to sustain the transparency rule. Because the nondiscrimination and the related nonblocking rules represented classic common carriage regulation, they ran afoul of the statutory provision prohibiting the use

25 The Policy Statement also stated that "consumers are entitled to competition among network providers, application and service providers, and content providers," but this provision has not played a significant role in the network neutrality debate.

26 Comcast v. FCC, 600 F.3d 642 (D.C. Cir. 2010). 
of Title I to regulate a service as a common carrier. The court did offer some specific guidance as to how the rules could be revised so that they could survive judicial review. ${ }^{27}$

The FCC's initial proposal to address these shortcomings adopted the court's suggestions, calling them a roadmap for promulgating network neutrality rules that would withstand judicial scrutiny (U.S. FCC, 2014a). A YouTube speech released by President Obama in the wake of the 2014 midterm elections changed the direction of the rulemaking towards the alternate approach of bringing broadband Internet access services (BIAS) within the Title II regime that has long governed traditional telephone service (U.S. President, 2014).

The resulting 2015 Open Internet Order enhanced the transparency requirements; enunciated bright-line rules that prohibited blocking, throttling, and paid prioritization; and adopted a general conduct standard prohibiting unreasonable interference or disadvantage. The 2015 Order maintained the exceptions for reasonable network management and specialized services (now renamed non-BIAS services), but abandoned the part of the previous order subjecting mobile broadband to a lower standard. The 2015 Order also moved beyond simply regulating how traffic is handled within a network by taking the further step of regulating interconnection between networks (U.S. FCC, 2015).

The D.C. Circuit upheld the 2015 Order in June $2016 .^{28}$ In January 2017, however, the Republican victory in the presidential election led to the appointment of a new FCC Chairman. The new appointee promulgated a notice of proposed rulemaking (NPRM) that would return to the consensus that governed from 2002 to 2015 that broadband Internet access should be governed by Title I instead of Title II. The NPRM also sought comment on what such Title I regulation should look like (U.S. FCC, 2017a).

27 Verizon v. FCC, 740 F.3d 623 (D.C. Cir. 2014).

28 U.S. Telecom Ass'n v. FCC, 825 F.3d 674 (D.C. Cir. 2016). 
At this point, the FCC's retreat from Title II appears to be a foregone conclusion, although the precise details of the final resolution of the current proposal remain to be seen. In the meantime, a few aspects of the network neutrality debate bear mentioning. As an initial matter, the scope has changed dramatically over the years, although the debate has been going on for more than a decade. The 2005 Policy Statement was focused entirely on the problems of blocking and interconnection. That debate was expanded in the 2010 Open Internet Order to include the additional concern about discrimination. And the 2015 Open Internet Order broadened the issues still further to include interconnection. In retrospect, it becomes clear that network neutrality has been something of a moving target.

In addition, the debate over Internet regulation has reflected the same patterns as the debates over voice and video. To date, judicial decisions have played a key role in shaping policy by striking down line sharing, requiring the specification of an affirmative grant of authority, and ensuring that any exercises of Title I authority not violate any other specific statutory provisions. The Line Sharing Order in particular accommodated the tension between static and dynamic efficiency that was also present with respect to voice and video by lifting access requirements whenever facilities-based competition ensured that service was available from a third party. In short, broadband policy continues to be shaped by concerns about static vs. dynamic efficiency, the importance of facilities-based competition, and the key role played by the courts in much the same manner as other communications technologies.

\section{Conclusion and a Look to the Future}

Looking back forty years from the vantage point of 2017 presents a fairly positive picture of U.S. communications policy. All of the challenges that were salient when Telecommunications Policy published its first issue - the lack of competition in CPE, long 
distance, local telephone service, television networks, and multichannel video program distribution— - have essentially been addressed. The other technology that has grown in importance since 1976 - the Internet—is widely regarded as a raging success.

Moreover, although no history is completely uniform, the past forty years illustrates the key considerations underlying the choice between whether to impose access regulations or whether to rely on facilities-based competition. In short, using access regulation to allocate the monopoly loop is appropriate when entry is infeasible and the network is already full built out, in which case the promotion of static efficiency is the only viable objective. When entry is feasible and consumers are demanding major new investments to support higher quality services, however, access regulations have the unfortunate consequence of frustrating dynamic efficiency by dampening incentives to invest and by making entry more difficult.

The other striking feature is the key role that the courts have played in promoting competition and consumer welfare. In many cases, timely judicial intervention has forced regulators to retreat from positions that protected incumbents and limited competition. Left to their own devices, agencies often exhibit too great a willingness to protect the existing regulatory regime.

Of course, new issues continue to arise, and the debates over U.S. communications policy continue. A host of issues are waiting in the wings, such as how to deal with the rise of over-thetop television platforms such as Netflix, the upcoming deployment of $5 \mathrm{G}$ wireless networks, and the advent of the Internet of Things (IoT). The high-technology sector is also experimenting with new modes of governance in which private entities, such as standard setting organizations and companies, have replaced governments and intergovernmental organizations as the key 
decisionmakers. And lurking over all of these debates is the burgeoning problem of security and privacy.

Only time will tell how the issues raised by these new developments will be resolved.

But if the past is any guide, it is certain that Telecommunications Policy and the research that it publishes will continue to play an influential role.

Acknowledgement: This article is an expanded version of a presentation at the Plenary Session on "Retrospective and Prospective of Telecommunications Policy Research" at the International Telecommunications Society Biennial Conference held in Taipei, Taiwan, on June 27, 2016. This research did not receive any specific grant from funding agencies in the public, commercial, or not-for-profit sectors. 


\section{References}

Besen, S., \& Crandall, R. (1981). The Deregulation of Cable Television. 44 Law \& Contemporary Problems, 44, 77-124

Bourreau, M., Doğan, P., \& Manant, M. (2010). A critical review of the "ladder of investment" approach. Telecommunications Policy, 34, 683-696.

Breyer, S. (1982). Regulation and Its Reform. Cambridge, MA: Harvard.

Cambini, C., and Jiang, Y. (2009). Broadband investment and regulation: A literature review. Telecommunications Policy, 33, 559-574.

Cave, M. (2006). Encouraging infrastructure competition via the ladder of investment. Telecommunications Policy, 30, 223-237

Cerf, V., \& Kahn, R. (1974). A Protocol for Packet Network Intercommunication. IEEE Transactions on Communications, 22, 637.

Day, L. (1976a). Telecommunications policy: Teamwork. Telecommunications Policy, 1, 2. . (1976b). Telecommunications policy research. Telecommunications Policy, 1, 90-91.

Dordick, H. (1977). Airlie House - a unique focus for policy research. Telecommunications Policy, 1, 437.

Faulhaber, G. (2003). Policy-induced competition: the telecommunications experiments. Information Economics and Policy, 15, 73-97.

Grajek, M., \& Röller, L.-H. (2012). Regulation and Investment in Network Industries: Evidence from European Telecoms. Journal of Law and Economics, 55, 189-216.

Hausman, J. (1997). Valuing the Effect of Regulation on New Services in Telecommunications. Brookings Papers: Microeconomics, 1-38.

— \& Sidak, J. (2005). Did Mandatory Unbundling Achieve Its Purpose? Empirical Evidence from Five Countries. Journal of Competition Law and Economics, 1, 173-245.

Hazlett, T. (2006). Rivalrous Telecommunications Networks With and Without Mandatory Sharing. Federal Communications Law Journal, 58, 477-509.

- (2017). The Political Spectrum: The Tumultuous Liberation of Wireless Technology, from Herbert Hoover to the Smart Phone. New Haven, CT: Yale.

Janson, M., \& Yoo, C. (2013). The Wires Go to War: The U.S. Experiment with Government Ownership of the Telephone System During World War I, Texas Law Review, 91, 9831050 . 
Kahn, A. (1971). The Economics of Regulation: Principles and Institutions. Cambridge, MA: MIT.

Lampert, Donna M. (1992). Cable Television: Does Leased Access Mean Least Access? Federal Communications Law Journal, 44, 245-284.

Rohlfs, J., Jackson, C., \& Kelley, T. (1991). Estimate of the Loss to the United States Caused by the FCC's Delay in Licensing Cellular Telecommunications. Washington, D.C.: National Economic Research Associates.

U.S. Bureau of the Census. (1975). Historical Statistics of the United States, Colonial Times to 1970, part 2. Washington, D.C.: U.S. Government Printing Office.

U.S. Congress. (1984). Cable Communications Policy Act of 1984, Pub. L. No. 98-549, 98 Stat. 2779

_. (1988). Trademark Law Revision Act of 1988, Pub. L. No. 100-667, 102 Stat. 3935.

. (1992). Cable Television Consumer Protection and Competition Act of 1992, Pub. L. No. $102-385,106$ Stat. 1460.

- (1996a). H.R. Conf. Rep. No. 104-458, reprinted in 1996 U.S.C.C.A.N. 124.

. (1996b). Telecommunications Act of 1996, Pub. L. No. 104-104, 110 Stat. 56.

. (1999). Consolidated Appropriations Act, Pub. L. No. 106-113, 113 Stat. 1501.

U.S. Federal Communications Commission. (1949). General Mobile Radio Services, Report and Order of the Commission, 13 F.C.C. 1190.

. (1951). Amendment of Section 3.606 of the Commission's Rules and Regulations, Fourth Report of Commission and Order, 41 F.C.C. 131.

. (1955). Hush-a-Phone Corp., Decision, 20 FCC Rcd. 391, rev'd, 238 F.2d 266 (D.C. Cir. 1956).

- (1965). Amendment of Subpart L, Part 11, to Adopt Rules and Regulations to Govern the Grant of Authorizations in the Business Radio Service for Microwave Stations to Relay Television Signals to Community Antenna Systems, First Report and Order, 38 F.C.C. 683.

- (1966). Amendment of Subpart L, Part 91, to Adopt Rules and Regulations to Govern the Grant of Authorizations in the Business Radio Service for Microwave Stations to Relay Television Signals to Community Antenna Systems, Second Report and Order, 2 F.C.C.2d 725, aff'd sub nom. U.S. v. Southwestern Cable Co., 392 U.S. 157 (1968). . (1968a). Use of the Carterfone Device in Message Toll Telephone Service, Decision, 13 F.C.C.2d 420. 
. (1968b). An Inquiry Relative to the Future Use of the Frequency Band 806-960 MHz, Notice of Inquiry and Notice of Proposed Rule Making, 14 F.C.C.2d 311.

. (1969). Amendment of Part 74, Subpart K, of the Commission's Rules and Regulations Relative to Community Antenna Television Systems, First Report and Order, 20

F.C.C.2d 201, rev'd sub nom. Home Box Office Inc. v. FCC, 567 F.2d 9, 36-51 (D.C. Cir. 1977).

. (1970a). An Inquiry Relative to the Future Use of the Frequency Band 806-960 MHz, First Report and Order and Second Notice of Inquiry, 19 Rad. Reg. 2d (P\&F) 1663.

. (1970b). Amendment of Part 73 of the Commission's Rules and Regulations with Respect to Competition and Responsibility in Network Television Broadcasting, Report and Order, 23 F.C.C.2d 382, aff'd sub nom. Mt. Mansfield Television, Inc. v. FCC, 442 F.2d 470 (2d Cir. 1971).

- (1971). Regulatory and Policy Problems Presented by the Interdependence of Computer and Communication Services and Facilities, Final Decision and Order, 28 F.C.C.2d 267.

. (1972). Amendment of Part 74, Subpart K, of the Commission's Rules and Regulations Relative to Community Antenna Television Systems, Cable Television Report and Order, 36 F.C.C.2d 141.

. (1974a). An Inquiry Relative to the Future Use of the Frequency Band 806-960 MHz, Second Report and Order, 46 F.C.C.2d 752.

. (1974b). Rules and Regulations Relative to Carriage of Late-Night Television Programming by Television Systems, Report and Order, 48 F.C.C.2d 699.

- (1975a). An Inquiry Relative to the Future Use of the Frequency Band 806-960 MHz, Memorandum Opinion and Order, 51 F.C.C.2d 945, aff'd sub nom. Nat'l Ass'n of Regulatory Util. Comm'rs v. FCC, 525 F.2d 630 (D.C. Cir. 1975).

(1975b). Proposals for New or Revised Classes of Interstate and Foreign Message Toll Telephone Service (MTS) and Wide Area Telephone Service (WATS), First Report and Order, 56 F.C.C.2d 593.

- (1976a). Rules and Regulations Relative to Cable Television Systems and the Carriage of Network News Programs on Cable Television Systems, Report and Order, 57 F.C.C.2d 68.

. (1976b). Rules and Regulations with Respect to Selection of Television Signals for Cable Television Carriage, Report and Order, 57 F.C.C.2d 625.

. (1976c). Rules and Regulations Relative to Adding a New Definition For "Specialty Stations" and Specialty Format Programming and Amending the Appropriate Signal Carriage Rules, First Report and Order, 58 F.C.C.2d 442. 
. (1976d). Proposals for New or Revised Classes of Interstate and Foreign Message Toll Telephone Service (MTS) and Wide Area Telephone Service (WATS), Second Report and Order, 58 F.C.C.2d 736, aff'd sub nom. N.C. Utils. Comm'n v. FCC, 552 F.2d 1036 (4th Cir. 1977).

. (1976e). Amendment of Pt. 76 of the Commission's Rules and Regulations Concerning the Cable Television Channel Capacity and Access Channel Regulations of Section 76.251, Report and Order, 59 F.C.C.2d 294.

. (1977). Rules and Regulations with Respect to the Definition of a Cable Television System and the Creation of Classes of Cable Systems, First Report and Order, 63 F.C.C.2d 956.

- (1980a). Amendment of Section 64.702 of the Commission's Rules and Regulations (Second Computer Inquiry), Final Decision, 77 F.C.C.2d 384, aff'd sub nom. Computer \& Commc'ns Indus. Ass'n v. FCC, 693 F.2d 198 (D.C. Cir. 1982).

(1980b). Cable Television Syndicated Program Exclusivity Rules and Inquiry into the Economic Relationship Between Television Broadcasting and Cable Television, Memorandum and Order, 79 F.C.C.2d 652.

_- (1980c). New Television Networks: Entry, Jurisdiction, Ownership, and Regulation. Washington, D.C.: Federal Communications Commission.

. (1981). An Inquiry into the Use of the Bands 825-845 MHz and 870-890 MHz for Cellular Communications Systems, Report and Order, 86 F.C.C.2d 469.

- (1982). Inquiry into the Development of Regulatory Policy in Regard to Direct Broadcast Satellites for the Period Following the 1983 Regional Administrative Radio Conference, Report and Order, 90 F.C.C.2d 676, vacated in part sub nom. Nat'l Ass'n of Broadcasters v. FCC, 740 F.2d 1190 (D.C. Cir. 1984).

- (1983a). Amendment of 47 CFR $\S 73.658(j)(1)(i)$ and (ii), the Syndication and Financial Interest Rules, Tentative Decision and Request for Further Comments, 94 F.C.C.2d 1019.

- (1983b). Policy and Rules Concerning the Furnishing of Customer Premises Equipment, Enhanced Services and Cellular Communications Services by the Bell Operating Companies, Report and Order, 95 F.C.C.2d 1117, aff'd sub nom. Ill. Bell Tel. Co. v. FCC, 740 F.2d 465 (7th Cir. 1984).

. (1990a). Evaluation of the Syndication and Financial Interest Rules, Notice of Proposed Rulemaking, 5 FCC Rcd. 1815.

. (1990b). Fox Broadcasting Co. Request for Temporary Waiver of Certain Provisions of 47 C.F.R. § 73.658, Memorandum Opinion and Order, 5 FCC Rcd. 3211. 
- (1991). Evaluation of the Syndication and Financial Interest Rules, Memorandum Opinion and Order, 7 FCC Rcd. 345, rev'd sub nom. Schurz Commc'ns, Inc. v. FCC, 982 F.2d 1043 (7th Cir. 1992).

. (1995a). Review of the Prime Time Access Rule, Report and Order, 11 FCC Rcd. 546.

. (1995b). Review of the Syndication and Financial Interest Rules, Report and Order, 10 FCC Rcd. 12165.

. (1997). Annual Assessment of the Status of Competition in the Market for the Delivery of Video Programming, Third Annual Report, 12 FCC Red. 2358.

. (1998a). Application of BellSouth Corp., BellSouth Telecommunications, Inc., and BellSouth Long Distance, Inc., for Provision of In-Region, InterLATA Services in Louisiana, Memorandum Opinion and Order, 13 FCC Rcd. 20599.

- (1998b). GTE Telephone Operating Cos., Memorandum Opinion and Order, 13 FCC Rcd. 22466.

. (1999). Deployment of Wireline Services Offering Advanced Telecommunications Capability, Third Report and Order in CC Docket No. 98-147 and Fourth Report and Order in CC Docket No. 96-98, 14 FCC Rcd. 20912.

- (2001a). Implementation of Section 3 of the Cable Television Consumer Protection and Competition Act of 1992, Report on Cable Industry Prices, 16 FCC Rcd. 4346.

- (2001b). Implementation of Section 6002(b) of the Omnibus Budget Reconciliation Act of 1993, Annual Report and Analysis of Competitive Market Conditions With Respect to Commercial Mobile Services, Sixth Report, 16 FCC Rcd. 13350.

- (2002). Inquiry Concerning High-Speed Access to the Internet over Cable and Other Facilities, Declaratory Ruling and Notice of Proposed Rulemaking, 17 FCC Rcd. 4798, aff'd sub nom. Nat'l Cable \& Telecomms. Ass'n v. Brand X Internet Servs., 545 U.S. 967 (2005).

- (2003a). Application by SBC Communications, Inc., Nevada Bell Telephone Co., and Southwestern Bell Communications Services, Inc., for Authorization to Provide InRegion, InterLATA Services in Nevada, Memorandum Opinion and Order, 18 FCC Rcd. 7196.

- (2003b). Application by Qwest Communications International, Inc., for Authorization to Provide In-Region, InterLATA Services in New Mexico, Oregon and South Dakota, Memorandum Opinion and Order, 18 FCC Rcd. 7325.

- (2003c). Review of the Section 251 Unbundling Obligations of Incumbent Local Exchange Carriers, Report and Order and Order on Remand and Further Notice of Proposed Rulemaking, 18 FCC Rcd. 16978, aff'd in part \& rev'd in part sub nom. U.S. Telecom Ass'n v. FCC, 359 F.3d 554 (D.C. Cir. 2004) 
. (2004). Application of AT\&T Wireless Services, Inc. \& Cingular Wireless Corp., Memorandum Opinion and Order, 19 FCC Rcd. 21522.

- (2005a). Annual Assessment of the Status of Competition in the Market for the Delivery of Video Programming, Eleventh Annual Report, 20 FCC Rcd. 2755.

- (2005b). Appropriate Framework for Broadband Access to the Internet over Wireline Facilities, Report and Order and Notice of Proposed Rulemaking, 20 FCC Rcd. 14853, aff'd sub nom. Time Warner Telecom, Inc. v. FCC, 507 F.3d 205 (3d Cir. 2007).

- (2005c). Appropriate Framework for Broadband Access to the Internet over Wireline Facilities, Policy Statement, 20 FCC Rcd. 14986.

- (2006). United Power Line Council's Petition for Declaratory Ruling Regarding the Classification of Broadband over Power Line Internet Access Service as an Information Service, Memorandum Opinion and Order, 10 FCC Rcd. 12165.

- (2007). Appropriate Regulatory Treatment for Broadband Access to the Internet over Wireless Networks, Declaratory Ruling, 22 FCC Rcd. 5901.

- (2008a). Formal Complaint of Free Press and Public Knowledge Against Comcast Corporation for Secretly Degrading Peer-to-Peer Applications, Memorandum Opinion and Order, 23 FCC Rcd. 13028, rev'd sub nom. Comcast v. FCC, 600 F.3d 642 (D.C. Cir. 2010).

- (2008b). Local Telephone Competition: Status as of December 31, 2007. Available at https://apps.fcc.gov/edocs_public/attachmatch/DOC-285509A1.pdf.

- (2009). Annual Assessment of the Status of Competition in the Market for the Delivery of Video Programming, Thirteenth Annual Report, 24 FCC Rcd. 542.

- (2010). Preserving the Open Internet, Report and Order, 25 FCC Rcd. 17905, aff'd in part, rev'd in part sub nom. Verizon v. FCC, 740 F.3d 623 (D.C. Cir. 2014).

. (2014a). Protecting and Promoting the Open Internet, Notice of Proposed Rulemaking, 29 FCC Rcd. 5561.

_. (2014b). Sports Blackout Rules, Report and Order, 29 FCC Rcd. 12053.

- (2014c). Local Telephone Competition: Status as of December 31, 2013. Available at https://apps.fcc.gov/edocs_public/attachmatch/DOC-329975A1.pdf.

- (2015). Protecting and Promoting the Open Internet, Report \& Order on Remand, Declaratory Ruling, and Order, 30 FCC Rcd. 5601, aff'd sub nom. U.S. Telecom Ass' $n$ v. FCC, 825 F.3d 674 (D.C. Cir. 2016).

- (2017a). Restoring Internet Freedom, Notice of Proposed Rulemaking, 32 FCC Rcd. 4434. 
- (2017b). Annual Assessment of the Status of Competition in the Market for the Delivery of Video Programming, Eighteenth Report, 32 FCC Rcd. 5260.

U.S. Pennsylvania Public Utility Commission. (2015). Joint Petition of Verizon Pennsylvania LLC And Verizon North LLC for Competitive Classification of all Retail Services in Certain Geographic Areas and for a Waiver of Regulations for Competitive Services, Opinion and Order. Available at http://www.puc.state.pa.us/pcdocs/1348740.docx

U.S. President. (2014). President Obama's Statement on Keeping the Internet Open and Free. Available at https://www.youtube.com/watch? $\mathrm{v}=\mathrm{uKcjQPVwfDk}$.

Wu, T. (2003). Network Neutrality, Broadband Discrimination. Journal on Telecommunications and High Technology Law, 2, 141-178.

—. (2004). The Broadband Debate: A User's Guide. Journal on Telecommunications and High Technology Law, 3, 69-95.

Yoo, C. (2002). Vertical Integration and Media Regulation in the New Economy, Yale Journal on Regulation, 19, 171-300.

—. (2004). Would Mandating Network Neutrality Help or Hurt Broadband Competition?: A Comment on the End-to-End Debate, Journal on Telecommunications and High Technology Law, 31, 23-68.

—. (2016). Modularity Theory and Internet Policy. University of Illinois Law Review 1-62. 